\title{
Regional integration in Africa versus higher levels of intra-Africa trade
}

\author{
Andre' C Jordaan ${ }^{1}$
}

\begin{abstract}
Regional integration arrangements have mushroomed worldwide, both on intra-regional and extra-regional levels. On an intra-regional level, Africa faces a complicated grid of multiple and overlapping membership of several regional integration organisations, aiming to increase intraregional trade and cooperation. In this study, a comparative analysis will be executed, based on an intra-regional breakdown of trade, using the United Nations Economic Commission for Africa classification of countries according to geographical region. The level of intra-regional trade will be determined, whereafter the level of inter-regional trade will be established and, lastly, trade with the rest of the world. It seems that despite the high level of regional integration within Africa, it does not necessarily stimulate intra-Africa trade to expected levels as proposed by literature. A regional integration strategy that would cause deeper integration is crucial if the continent is to play a rightful role in the global arena.
\end{abstract}

Keywords: regional integration; intra-Africa trade; intra-regional trade; inter-regional trade; Africa

\section{Introduction}

Since the early years of independence in Africa, regional integration has pre-occupied many in Africa who believed that it was the main instrument to promote economic growth and development. This belief was a driving force in the formation of the Organization of African Unity in 1963, currently the African Union. It was a first step towards closer unity on the African continent and the realisation of this dream. Since the era of decolonisation, regionalism has proliferated on the African continent, although the level of economic progress has not met the expectations. Regional integration in Africa has given birth to very few real successes, mainly because of significant challenges such as inadequate financial resources in most countries to enforce systems and regional commitments, economic instability and numerous sub-groupings. Although there have been many efforts by countries to strengthen their regional groupings, the improvement in higher intra-Africa trade remains lower than projected because of the slow implementation to eliminate tariff and non-tariff barriers, amongst other.

Regional integration arrangements have mushroomed worldwide, both on intra-regional and extra-regional levels. The multiple memberships of numerous regional economic communities (RECs) have seemingly contributed to the slow progress of inter-regional integration on the African continent (United Nations Economic Commission for Africa [UNECA], 2010). On an intra-regional level, Africa faces a complicated grid of multiple and overlapping membership of several of these regional integration organisations, aiming to increase intra-regional trade and cooperation. However, in general it seems as if Africa trades less with itself than with its developed nation

\footnotetext{
${ }^{1}$ Professor, Department of Economics, University of Pretoria, Pretoria 0002, South Africa. Correspondence: andre.jordaan@up.ac.za
} 
trading partners. Due to the pervasive political economy of the above-mentioned fact, production patterns are geared towards servicing these trading partners. The appropriateness of integration modalities may hamper expansion of regional trade because not all countries are at the same level of economic development. Furthermore, the narrow range of primary products and the lack of product diversification mean that very few complementarities exist to enhance trade between African countries. The benefits of regional integration under these circumstances invariably accrue to the most advanced economy. Countries who managed to enhance their links with the global economy have actually experienced higher growth rates.

In this study, a comparative analysis will be executed based on an intra-regional breakdown of trade, using the UNECA classification of countries according to geographical region (see Appendix A, Table A1). The analysis will be based upon the trade extent between the southern (11 countries), northern (seven countries), eastern (13 countries), western (15 countries) and central (seven countries) African countries, and the rest of the world. The rest of the paper is organised as follows. Section 2 discusses the justification for economic integration, while Section 3 describes the regional integration in Africa and whether the high level of regional integration within Africa does stimulate trade among them. Section 4 analyses intra-African trade, while Section 5 draws conclusions from the analysis.

\section{Justification for economic integration}

Frankel \& Rose (2000) demonstrate that, on average, regional trade arrangements can have a positive effect on intra-regional trade. Regional integration is therefore seen as a pathway to ensure easier access to bigger markets and increased levels of trade resulting in higher economic growth. Countries participating in trade derive significant welfare gains from it, although not necessarily in an equitable way. In most trading relationships, there will be winners and losers (UNECA, 2010). However, universal agreement exist that trade in general promotes economic growth because trade stimulates the allocation of resources based on the perceived comparative advantage of participating countries.

Two very important reasons why regional integration is pursued among countries are the allocation effect and the accumulation or growth effect. In general, with respect to the allocation effect, the demand for goods directs productive resources to the production of that good. However, protectionist measures such as tariffs distort this approach, so the removal of these barriers is perceived as increasing efficiency in resource allocation. An outcome of the allocation effect is the scale and variety effects. The former refers to the protection of inefficient firms that would be removed within a trade block, rationalising entire industries through the reallocation of resources. The latter refer to the availability of a larger variety of goods once a country's economy is integrated in a bigger market to increase welfare levels in that country. This also opens the possibility to choose from a wider group of production factors to increase productivity (UNCTAD, 2009).

With regard to the accumulation or growth effect, regional integration expands regional markets and attracts more suppliers, and therefore specialisation opportunities arise. Technological spillovers as a consequence of regionalism result in higher productivity and lower production costs, attracting additional investment and hence factor accumulation. This combined effect is believed to have a positive impact on economic 
growth. Given this, regional integration seems to have all the ingredients needed to foster growth and development to enable the region a higher level of participation in the global economy (UNCTAD, 2009).

A very important aspect highlighted by Schiff \& Winters (2003) is that the benefits of regional integration largely depend on finding the best partners. According to them, the 'natural' trading partner is not necessarily the best partner. Here, the obvious tendency to form trade blocs between neighbouring countries comes to mind. The attraction in reducing trade costs, relaxing border formalities and simplifying the process of collecting tax revenues are generally seen as driving the process of selecting partners. Schiff \& Winters (2003) argue that developing countries pursuing regional integration will be better off with partners from large, rich countries compared with small poor ones. Another point raised by them is that multiple membership may be beneficial given that these arrangements are compatible but there are potential problems with this approach. Conflicting aspects such as policies with third parties, different regulations governing imports and different technical standards may all contribute to complicating the arrangement.

The formation of a regional bloc is not supposed to be activity neutral. It should naturally lead to changes in composition and size of economic activities among countries both within the bloc and between the bloc and the rest of the world. This is the basis of the oftcelebrated trade-creation and trade-diversion theory proposed by Viner (1950). Since Viner's seminal publication to date, there is yet to be consensus among trade economists as to the exact nature or size of the impact of regional integration agreements (RIAs). This is partially on account of the complex nature of associated economic, policy and cultural environments existing among nations forming an RIA as well as the nature of the protocols guiding each particular RIA. For example, it is acknowledged that the level of welfare existing among participating countries, prior to the formation of an RIA, heavily impacts on trade relationships among participating countries and even between members of the bloc and the rest of the world. Equally, efficiency of institutions within member countries and capacity to carry out requirements of agreed-on protocols matter significantly in determining overall outcomes of regional integration. Schiff \& Winters (2003) add to this by emphasising the modes of policy integration, which are coordination, harmonisation and acceptance or recognition or foreign regulatory regimes. Coordination implies the efforts of governments to align national policies and measures. Harmonisation is the adoption of similar rules or the negotiation of a mutual set of rules between countries. Recognition is where one country adopts (or recognises) another country's norms or standards.

The above formed the crux of Venables' (1999) treatise that examined the nature of South-South trade agreements as opposed to their North-South counterparts. Venables considered the following issues to determine how the formation of a free trade area or customs union affects the distribution of activity within the area. He wanted to establish whether the gains (or losses) are divided between members, or whether some gain while others lose. Another issue was whether the real income of member countries tends to converge or diverge. Two strands of literature were used. namely the comparative advantage theory and the literature on the importance of agglomeration forces, as bases for analysing who gains and who loses in a regional trade agreement (RTA). It was shown that a country's risk of trade diversion from a free trade agreement (FTA) increases with the difference of its comparative advantage 
relative to the group's average. This implies that for a group of low-income countries in an FTA, possibilities are high that the lowest income members would suffer a real income loss due to trade diversion. Relatively higher income countries, on the other hand, would tend to pull lower income members upwards, leading to income convergence. Likewise, in an RTA involving only low-income countries, agglomeration forces that induce spatial clustering of economic activities will result in the concentration of activities in some sections of the RTA at the expense of the rest. The result is more divergence in income of the participating countries, with the section/country of agglomeration moving ahead of the others. Based on these two arguments, Venables concluded that an FTA involving only developing countries (South-South trade agreements) will probably lead to income divergence, with the relatively richer countries benefiting at the expense of the poorer ones. Examples such as Kenya in the East Africa Community and South Africa in the Southern African Customs Union may be cited. In addition, RTAs such as the East African Common Market, the Central American Common Market and the Economic Community of West African States have all led to more income divergence among members. In contrast, RTAs between a high-income country or group of high-income countries and developing countries (North-South trade agreements) will lead to income convergence. To support this position, he cited the European Union (EU) experience that apparently has led to more convergence and narrowing of income gap between the lower income members of the EU and the highincome centre.

Some authors such as Soko (2007) and Aminian et al. (2008) view the outcome of integration from a slightly different perspective. Soko (2007) makes a distinction between policy-induced and market-induced regional integration. Policy-induced processes are seen as agreements based on treaties made by the policy-making elite in response to changes in the world economy. The result is an agreement based on the process of negotiations and bargaining. Market-induced integration is a process of regionalisation that is driven mainly by private actors. Regional integration, therefore, is a balance between challenges in the global economy and within specific policy areas.

Aminian et al. (2008) continue in a similar fashion - integration by agreements versus integration by markets. In the latter case, existing economic interactions precede formalisation of economic integration while in the former, economic policy institutions draw out plans for integration as an incentive for increased economic interaction among agents within the grouping. By taking a tour of developing Asia (which has experienced more integration by markets) and Latin America (which has more cases of integration by agreements), they tried to show that the outcomes from a regional integration arrangement depends critically on what is leading it. The East Asian economies considered include the Association of South East Asian countries (Cambodia, Indonesia, Malaysia, Philippines, Singapore, Thailand and Vietnam) and North East Asian countries (China, Hong Kong, Japan, Macao, South Korea and Taiwan), while the Latin American economies considered include the ANDEAN countries (Bolivia, Colombia, Ecuador, Peru and Venezuela) and MERCOSUR (Argentina, Brazil, Paraguay, Uruguay and Venezuela).

The analysis starts with a conventional comparison of the size of intra-group trade among regional groupings in the two regions. This was followed by an assessment of trade intensity for the two regions using a standard trade intensity index. Thirdly, the work assumed that the principal motive for the 'new regionalism' move among small developing economies is to design rules to attract more foreign direct investment and 
strengthen institutions for participating in global production sharing (Ethier, 1998; Salazar-Xirinachs, 2005). As such, it examined the competitiveness of countries in the two regions in items such as 'components and parts' using the revealed comparative advantage index. They calculated the revealed comparative advantage for exports and separated this from revealed comparative advantage for imports in order to evaluate the comparative advantage in processing. Their findings were that, despite the relative lack of formal regional trade pacts until recently, East Asia is more integrated among itself than Latin America. So they conclude that the proper sequence of integration seems to be first integrating via markets and subsequently via formal RTAs. This, in their view, will have the added advantage of enhancing the political bargaining power of outwardoriented economic forces within a country.

Aminian et al.'s (2008) work raises an issue that has been at the heart of debate in the theory of regional integration and is far from settled. It seems that even where there seems to be no strong evidence for integration of markets, trading agreements are still entered into, implying that practice may differ significantly from theory in this respect for other reasons. However, despite findings such as those of Aminian et al., it seems difficult to completely discount the potential merits of regional trade arrangements, particularly of developing countries on the grounds of de facto weak integration prior to trade agreements. That is the position of Coulibaly (2007), who investigated seven RTAs in developing regions - including the Economic Community of West African States, the South African Development Community (SADC) in sub-Saharan Africa, the Association of South East Asian Free Trade Area, the South Asia Association for Regional Cooperation, the South Asia Preferential Trade Arrangement (SAPTA) in Asia, the Central American Common Market, and the Southern American Common Market (MERCOSUR) in Latin America. However, instead of using a dummy variable to represent participation in RTAs as is the practice in many research studies, the author uses a semi-parametric approach that accounts for the number of years of membership in the RTA by each country. By combining a gravity model with kernel estimation with data covering 1960 through 1999, the author minimised efforts to impose structure on the model. He found that with the exception of SAPTA, the RTA has had a significant positive impact on their members' intra-group trade with the Asia-Pacific Trade Agreement (APTA) leading the pack. The Economic Community of West African States' impact on members' intra-group trade seems to have fizzled out after the first 10 years of its existence. Lastly, the author attributed the poor outcomes in SAPTA to tensions between India and Pakistan over the period covered by the data.

It is largely agreed in the literature that whether or not there is enough 'integration of markets' prior to the formation of an RIA as canvassed by Aminian et al. (2008) o r whether there would be enough integration of markets following the RIA formation as shown by Coulibaly (2007) depends on a number of factors. Besides the structure of production, one critical factor amongst others is the state of trade facilitation in participating countries. Consequently, a number of studies have looked at the trade facilitation challenge to multilateral and unilateral liberalisation as well as regional integration and intra-group trade flows. Using different constructs of trade facilitation measures and different shades of empirical models, the conclusions seem to be identical that these measures matter significantly for trade and growth (Limao \& Venables, 2001; UNCTAD, 2001). It notes that the margins of gains are higher, the lower a country's initial conditions in efficiency of customs administration. 


\section{Regional integration in Africa}

Independent Africa perceived increased trade through regionalism as the universal remedy for the twin problems of slow rates of economic growth and alleviation of poverty on the continent. The then Organisation of African Unity, supported by UNECA drafted the Lagos Plan of Action in 1980 with the objective of establishing the African Economic Community (AEC). The Abuja Treaty, signed in 1991, followed and the continent was divided into five regional areas, namely north, south, east, west and central Africa, in preparation for the formation of the AEC (Draper et al., 2007). The establishment of various RECs was aimed at creating nerve centres for the formation of the AEC by 2028. African leaders agreed in 1991 to develop FTAs in each REC, followed by a customs union. This move eventually involves a continent-wide customs union with the removal of tariffs and quotas between members and the creation of a common external tariff. Ultimately, this process would serve as building blocks for achieving the final objective of an AEC.

The theory of comparative advantage promotes the idea that increased trade integration causes trade openness with higher subsequent levels of consumption and income through specialisation and division of labour (Winters \& Masters, 2010). Furthermore, three key channels are identified that can impact on growth and income levels through trade openness. These key channels are the transmission of technological innovation, facilitating competition and economies of scale (Winters, 2004). Technological spillovers are a key source of economic growth and trade barriers can impede on the free flow of technology and ultimately long-term growth, especially harming Africa. Trade openness can also enforce lower costs through an increase in competition, increase in productivity and enhanced efficiency. If returns in the import competing sector are lowered and increased in the export sector, trade openness causes a reallocation of resources from the lower to higher productivity firms and sectors, and hence faster growth. Trade openness facilitates access to larger markets, allowing firms to reap the benefits of economies of scale and further cost reductions. No country has grown in a sustained manner in recent times without increasingly integrating itself in the global economy. During the 1990s, per-capita income grew more than three times faster in developing countries that lowered their trade barriers (5\% per year), compared with other developing countries (1.4\% per year) (Winters,

2004).

Given the positions of theory and official rhetoric in many African countries, trade among themselves should have far outperformed their current levels. With bilateral and multilateral tariffs at historical lows given unilateral, bilateral and multilateral trade liberalisation, it is expected that trade among these countries should grow phenomenally. That this has not happened gives reason to seriously consider Baldwin's assertion that while the close of the twentieth century has seen considerable actualisation of the original goal of the General Agreement on Trade and Tariff of gradual abolishment of tariffs and quotas, the playing field is yet far from being level. In Baldwin's words: ‘[t]he lowering of tariffs has, in effect, been like draining a swamp. The lower water level has revealed all the snags and stumps of non-tariff barriers that still have to be cleared away'. These 'snags and stumps', consisting mainly of regulatory regimes, standards and technical regulations and port-related inefficiencies, doubtless present considerable barriers to trade and increase overall transaction costs for tradables (Hoekman et al., 2002). 


\subsection{Multiple memberships}

A notable characteristic of regional integration in Africa has been the multitude of regional integration initiatives ultimately leading to the formation of numerous RTAs. African countries have embraced regionalism, and currently there are more regional groupings in Africa than in any other continent. The African RTA's come closest to the conventional concept of regional integration based on geographic proximity (Fiorentino et al., 2007). It seems that regional integration is perceived as the basis to address barriers to intra-African trade. Once these barriers are removed through the process of regional integration, larger regional markets can sustain production systems through economies of scale to improve overall competitiveness and higher growth. Regional integration was aimed at restructuring the fragmented continent into a stronger and more coherent, self-reliant economic unit (UNCTAD, 2009). However, multiple and overlapping memberships imposes a constraint on regional integration by creating a complex entanglement of political commitments and institutional requirements adding to overall costs.

The agreements and overlapping membership in the same region tend to cause disorder in terms of setting and achieving productive economic objectives (UNCTAD, 2009). Between the 53 African countries, 31 are members of two regional groupings, 19 belong to three groups and one country is a member of four groupings. Only three countries have maintained membership in one block (see Appendix A, Table A2). The significant membership overlap also often creates conflicting policy objectives (Te Velde, 2008). Lewis (2001) finds the overlapping memberships a challenge that constrains the growth prospects in the SADC region. He states that on being a member of more than one regional arrangement, the country's commitment towards the various arrangements can be questioned. It also means a country has to use additional resources and capacity, which may be limited, to participate in these regional groupings. This can create inconsistencies and lack of cooperation amongst members. As many African countries became members of more than one REC, the enormous potential returns from regional integration evaporated in the face of different Rules of Origin, tariffs and customs procedures that cause delays, confusion and increased trade costs (DFID, 2011).

Regional integration generally results in efficiency gains and thus higher growth spillovers, especially for smaller and poorer economies (Te Velde, 2008). However, Africa's record in regional integration has been rather disappointing, despite the formation of over 200 regional cooperation organisations (So"derbaum, 1996). The successes of African regional schemes have been rather limited without producing discernible benefits, with the exception of the francophone West Africa and Southern Africa achieving only partial success (Mistry, 2000). Governments defaulting on regional commitments can partly be explained by an absence of monitoring and enforcement systems, due to weak secretariats on the regional level. The design of regional organisations have an inherent flaw, as member states have aimed at granting as little power as possible to the supra-national level. This unwillingness to surrender the essential elements of sovereignty to regional institutions has been common among regional agreements. Many of the regional integration initiatives did not accept the supra-national authority of the institution and were overly ambitious with multiple memberships being unclear and confusing (UNCTAD, 2009). Soloaga \& Winters (2001) show that regional blocs that were formed in the $1990 \mathrm{~s}$ had not led to additional intra-regional trade. However, the formation of regional groupings has been 
very popular among African countries even though it did not produce any real benefits to members. In some cases, the existence of a cooperation agreement alone may be beneficial to a participating country. It may spark some investors' interest in the region and this by itself may produce certain limited benefits, even if members had no intention of carrying out their regional commitments (Mistry, 2000). The perceive benefits associated with regional integration can be an incentive for smaller and poorer economies to be part of a regional arrangement.

Notwithstanding the existence of various regional trade arrangements, trade of most African countries is still influenced by historical and colonial ties. The majority of African exports are still destined to non-African countries, despite geographical proximity within the continent. More than $80 \%$ of Africa's exports are to destinations outside Africa, whereas imports are sourced outside Africa in $90 \%$ of the cases. This is rather disappointing given the abundance of natural resources available on the African continent (Hartzenberg, 2011). Collectively, the regional integration efforts have not done much in terms of economic progress and improving economic conditions of member countries. According to Fiorentino et al. (2007), this is evident from their low level of intra-regional trade, poor implementation of numerous agreements, and overlapping membership. Compared with regional groupings from Asia and Latin America, intra-regional trade as a proportion of total trade remains much lower in Africa (UNCTAD, 2009). The bulk of exports are undifferentiated commodities that are not needed in regional supply chains because of the serious underdevelopment of the manufacturing industry, South Africa being the notable exception. It is therefore fairly obvious that South Africa is an unimportant export destination for the region (Draper et al., 2007).

\subsection{Other constraining factors}

Despite the establishment of various institutions and initiatives, many challenges persist, such as inadequate financial resources. Over the years, many studies have highlighted the perceived benefits of regional integration such as improved resource allocation, transfer of technology and higher standards of living. Other studies have shown that integration has caused trade imbalances, increased financial volatility and sub-optimal macroeconomic policies. It seems, however, that consensus exists about the fact that national borders present considerably more barriers to regional integration than what was expected.

Regional integration arrangements can be costly, especially if run inefficiently associated with a lack of regional cooperation, which could limit potential gains. Khandelwal (2004) argues that progress in the SADC region is constraint by bottlenecks such as distortions in trade regimes, inadequacies in customs, transport and communication infrastructure. The World Bank's (2011) African competitiveness report states transport modes and trade facilitation regimes as factors that hinder growth in most African countries and therefore limit their ability to become regional players. Transport costs in Africa are regarded as the highest in the world. Limao \& Venables (2001) inevitably signify infrastructure as an important determinant of transportation costs, especially for landlocked countries. In their findings, the median transport costs for a landlocked country are about $46 \%$, which is higher than the equivalent cost in the median coastal economy. Distance accounts for only $10 \%$ of the difference in transport costs (Limao \& Venables, 2001). Transport costs for 15 sub-Saharan Africa 
landlocked countries are as high as $77 \%$ of the value of exports (UNECA, 2010). Poor road infrastructure accounts for $60 \%$ of transport costs in landlocked countries, which is 20 percentage points higher than in coastal countries. Longo \& Sekkat (2001) further established that if an importing or an exporting country is landlocked, intraregional trade is $2 \%$ less than what it would be if these countries were not landlocked.

After nearly three decades of regional integration in SADC, it is helpful to ask to what extent the regional integration project has promoted its most important goal of improving trade. This is a basic auditing and re-focusing procedure, which ideally should be undertaken by the SADC secretariat or country trade departments. However, while these institutions have invested heavily into paper work for improving cooperation, little is being done to examine the impact of previous trade protocols on overall trade or to gauge trade prospects given available trade facilitation measures - a minimum requirement for improving future trade relations (SADC, 1996). The implication has been a sizable multiplication of protocols but with little 'trade on the ground'. It seems that the large number of RIAs has done little to enhance intra-regional trade (Hartzenberg, 2011). However, further integration, as in many other regional integration arrangements, has been anchored on the ability of the individual countries to attain set macroeconomic convergence criteria. In this direction, other parts of Africa face the same problem working towards full integration anchored on convergence criteria. Economic performances are very volatile given that the bulk of the economies depend largely on the primary sector and an uncertain international market for these products. Outcomes of major macroeconomic indicators depend largely on the vagaries of weather, international price of crude oil, changing prices of agricultural products, and so forth. As such, progress towards the achievement of the criteria is largely epileptic with countries moving forward and backward each year depending on the direction of domestic policies aimed at ameliorating the negative forces that face each country (Kalenga, 2009). Other factors holding back progress in Africa include a high dependency on taxes as a source of revenue by some countries. Dependency on tax as a sole source of revenue is a major concern because countries may experience less benefit from regional arrangements as this will result in a loss of tariff revenue (Piazolo, 2002). This is echoed by Khandelwal (2004), stating that it is commonly difficult for small economies to replace lost tariff revenue with revenue from other sources.

Foroutan \& Pritchett (1993) find that the low degree of intra-regional trade is explained by the low degree of trade potential amongst African countries because of their generally low levels of gross domestic product. Africa's trade potential has also been constrained by restrictive trade orientation, macroeconomic policy failure, a lack of well-developed institutions, poor economic and political governance, and financial depth (UNECA, 2010). Further reasons for the failure of achieving higher levels of intra-regional trade amongst African countries rely on poor initial conditions such as implementation problems and basic design deficiency issues. Constraints such as a lack of complementarities among regional partners in terms of products and factors of production, potential for product differentiation linked to different income levels and consumption patterns are evident. Other challenges that are constraining achieving successful regionalism include dependence on trade taxes, poor regional infrastructure and administrative issues (Te Velde, 2008). The absence of support from a strong private sector and non-implementation of agreed liberalisation schedules further slowed any progress. It seems as if weak states may also be one of the constraints in developing robust rule-based RIAs as they are unable to develop, manage and implement a thorough regional agenda (Hartzenberg, 2011). 


\section{African regions GDP \\ (2005 constant prices)}

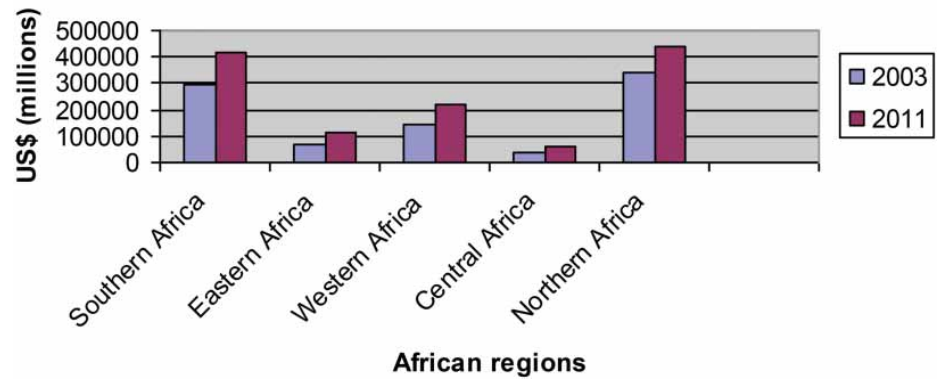

Figure 1: Gross domestic product (GDP) of African regions

Source: www.unctad.org

\section{Regional African trade}

While regional integration efforts multiplied across Africa, specific treatment of intragroup trade and implications of alternative scenarios for trade facilitation on overall trade and welfare is weak. Africa has small national economies, fragmented markets and constrained access to the ocean (DFID, 2011). Furthermore, trade among African countries is more tedious, costly and time-consuming than elsewhere in the world (Hartzenberg, 2011). As mentioned earlier, RIAs have mushroomed worldwide on various levels. A complicated grid of regional integration organisations with multiple and overlapping memberships pose a direct danger to increases in intra-regional trade. Africa trades far less with itself than with its developed nation trading partners, to the detriment of the whole continent. The narrow range of primary products and the lack of product diversification mean that very few complementarities exist to enhance intraAfrican trade with production patterns geared towards servicing non-African trading partners.

In this study, a comparative analysis is executed based on an intra-regional breakdown of trade, using the UNECA list of countries according to geographical region. Figure 1 provides some comparison among the various regions in terms of gross domestic product (GDP) for 2003 and 2011. From this it is clear that Central Africa and Eastern Africa are the smaller regions, while the Southern Africa and Northern Africa regions are the bigger regions in terms of gross domestic product.

The analysis is based upon the trade extent between the south, east, west, central and north African countries, and the rest of the world. Firstly, total exports among each region of countries and between regions will be discussed. Secondly, total imports among each region of countries and between regions will be described. Lastly, total trade (exports and imports) between each region of countries and the rest of the world will be analysed. Data were collected from the UNCTAD database from 2003 until 2011. ${ }^{2}$

\subsection{Intra-Africa trade}

Firstly, total exports among each region of countries will be analysed and are shown in Table 1. It is clear from Table 1 that regional exports are mainly between countries of the

\footnotetext{
${ }^{2}$ Assistance from R Hefer is acknowledged.
} 
same region. Total exports from the Southern African region to other countries in the southern region amounted to $8 \%$ in 2011. Exports from the Southern African region to the other individual regions were $1 \%$ or less of total exports in each case, and are therefore not shown. Total exports from Eastern Africa to other countries in the eastern region amounted to $15 \%$ in 2011. Total exports from Eastern Africa to the southern region amounted to $4 \%$ in 2011 , while exports to the other individual regions were $1 \%$ or less of total exports in each case. Total exports from Western Africa to other countries in the western region amounted to $8 \%$ in 2011. Total exports from Western Africa to the southern region amounted to $4 \%$ in 2011 , while exports to the other individual regions were $1 \%$ or less of total exports in each case. Total exports from the Central African region to other countries in the central region amounted to $2 \%$ in 2011. Exports from the Central African region to the other individual regions were $1 \%$ or less of total exports in each case. Total exports from the Northern African region to other countries in the northern region amounted to 5\% in 2011. Exports from the Northern African region to the other individual regions were $1 \%$ or less of total exports in each case.

From these figures it is evident that exports are mainly between countries of the same region, with the exception of a small number of exports to Southern Africa, originating from Eastern Africa and Western Africa. Total exports in 2011 within the Eastern African (15\%), Southern African (8\%) and Western African (8\%) regions are slightly higher compared with exports among the Northern African (5\%) and Central African $(2 \%)$ countries.

Secondly, total imports among each region of countries will be analysed and are shown in Table 2. It is clear from this table that regional imports are mainly from countries within the same region. However, it is notable that, with the exception of Northern Africa, all regions source a certain portion of imports from the Southern African region. Total imports of the Southern African region from other countries in the southern region amounted to $12 \%$ in 2011.Total imports of Southern Africa from the western region amounted to $2 \%$ in 2011, while imports from the other individual regions made up $1 \%$ or less of total imports in each case and are therefore not shown. Total imports of Eastern Africa from other countries in the eastern region amounted to 7\% in 2011. Total imports of Eastern Africa from the southern region amounted to $9 \%$ in 2011, while imports from the other individual regions were $1 \%$ or less of total imports in each case. Total imports of Western Africa from other countries in the western region amounted to $9 \%$ in 2011. Total imports of Western Africa from the southern region amounted to $2 \%$ in 2011, while imports from the other individual regions were $1 \%$ or less of total imports in each case. Total imports of the Central African region from other countries in the central region amounted to $4 \%$ in 2011. Imports of the Central African region from the western region amounted to $8 \%$ in 2011 , from the southern region amounted to $2 \%$ in 2011 and from the northern region amounted to $2 \%$ in 2011. Imports of the Central African region from the western region were $1 \%$ or less. Total imports of the Northern African region from other countries in the northern region amounted to $3 \%$ in 2011. Imports of the Northern African region from the other individual regions were $1 \%$ or less of total imports in each case.

From these figures it is evident that total imports among countries of the same region are not necessarily higher compared with imports from other regions, with the exception of Southern Africa (12\% in 2011), Western Africa (9\% in 2011) and Northern Africa (3\% in 2011). Eastern Africa imports mainly from Southern Africa (9\% in 2011), compared with 
Table 1: Total regional exports

\begin{tabular}{lcccc} 
Region & Total Exports to & $\mathbf{2 0 0 3}(\boldsymbol{\%})$ & $\mathbf{2 0 0 7}(\boldsymbol{\%})$ & $\mathbf{2 0 1 1}(\boldsymbol{\%})$ \\
\hline South & South & 10 & 9 & 8 \\
East & East & 16 & 15 & 15 \\
& South & 3 & 5 & 4 \\
West & West & 10 & 9 & 8 \\
& South & 2 & 3 & 4 \\
Central & Central & 2 & 2 & 2 \\
North & North & 3 & 3 & 5 \\
\hline
\end{tabular}

Source: www.unctad.org and author's own calculations.

own-region imports of $7 \%$ in 2011, and Central Africa imports mainly from Western Africa (8\% in 2011), compared with own-region imports of 4\% in 2011. Central Africa is one of the few regions that import $2 \%$ and more from three other African regions, namely Western Africa (8\%), Southern Africa (2\%) and Northern Africa (2\%).

It is important to determine the type of products traded within and among the African countries. The main export products destined for the regions and the main import products sourced from other regions in 2011 are provided in Appendix A (see Tables A3 and A4). From these tables it is evident that the majority of traded goods originate from the primary sectors. The level of product diversification is fairly limited, with the exception of Southern Africa, which is the only region exporting manufactured goods to other regions. Western Africa and Northern Africa import motor vehicles and Central Africa imports ships, boats and floating structures from Southern Africa.

In Figure 2, trade with the rest of the world is excluded and only intra-regional and interregional trade (exports plus imports) is analysed. From Figure 2, one can conclude that intra-regional trade is, as expected, relatively higher than inter-regional trade. The African map indicates Southern Africa (green), Eastern Africa (orange), Central Africa (yellow), Western Africa (pink) and Northern Africa (blue). The leading

Table 2: Total regional imports

\begin{tabular}{lcccc} 
Region & Total imports from & $\mathbf{2 0 0 3}$ & $\mathbf{2 0 0 7}(\boldsymbol{\%})$ & $\mathbf{2 0 1 1}(\boldsymbol{\%})$ \\
\hline \multirow{2}{*}{ South } & South & 18 & 14 & 12 \\
& West & 1 & 1 & 2 \\
\multirow{2}{*}{ East } & East & 9 & 7 & 7 \\
& South & 10 & 10 & 9 \\
\multirow{2}{*}{ West } & West & 13 & 10 & 9 \\
& South & 2 & 2 & 2 \\
Central & Central & 4 & 6 & 4 \\
& West & 8 & 12 & 8 \\
& South & 2 & 2 & 2 \\
& North & 1 & 2 & 2 \\
North & North & 4 & 4 & 3 \\
\hline
\end{tabular}

Source: www.unctad.org and author's own calculations. 


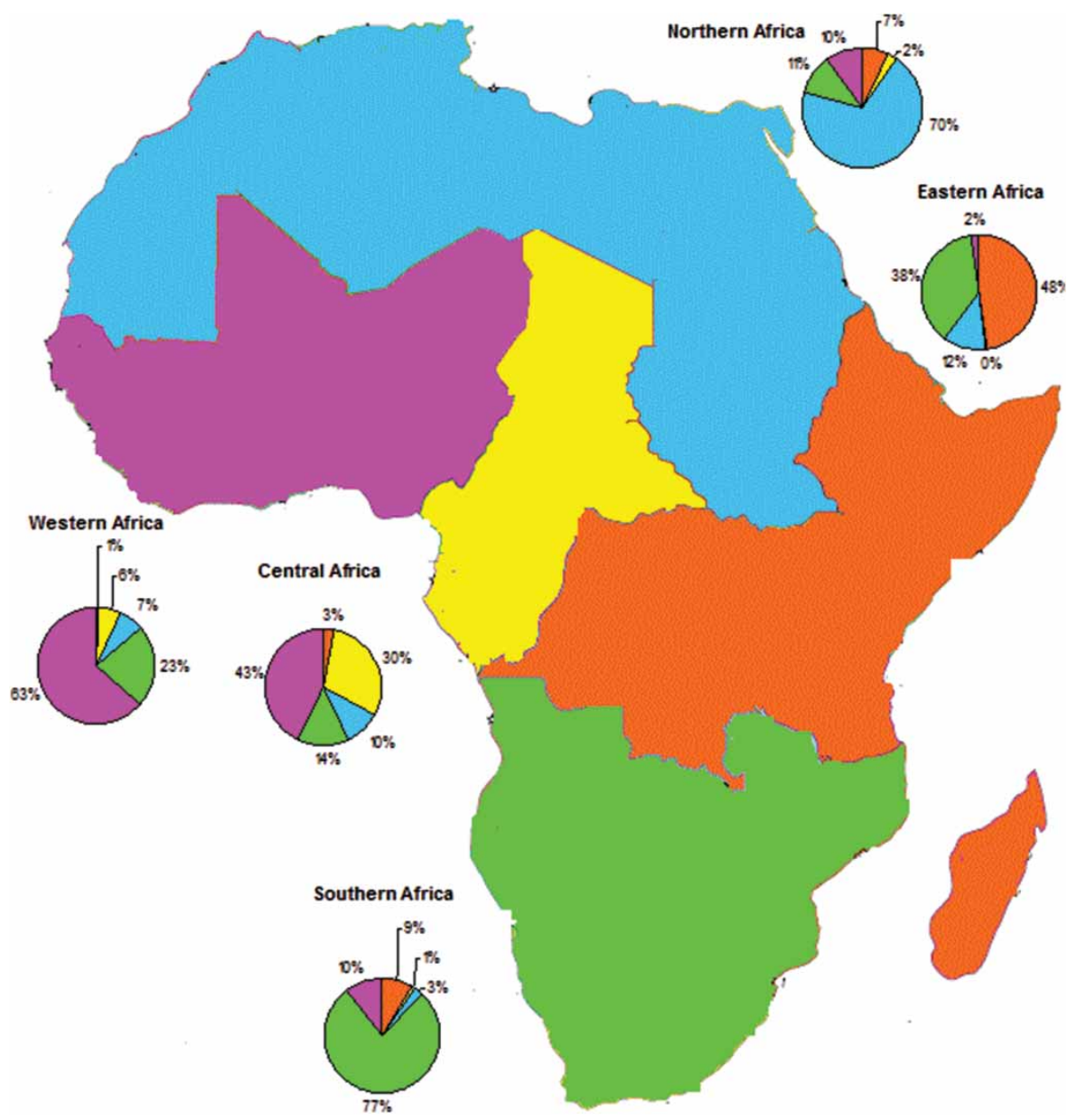

Figure 2: Intra-regional and inter-regional trade in Africa (2011)

Source: www.unctag.org

regions mainly trade among themselves as indicated by the Southern African (77\%), Northern African (70\%) and Western African (63\%) intra-regional trade. It seems as if the dominant region is clearly Southern Africa because most regions have a relatively larger trade share with the southern region. Trade of the Eastern African (38\%), Western African (23\%), Central African (14\%) and Northern African (11\%) regions with Southern Africa is clearly the largest portion of their inter-regional trade, apart from intra-regional trade. Furthermore, Central Africa is the only region where inter-regional trade with West Africa (43\%) is larger than intra-regional trade within the Central African (30\%) region. In addition, Central Africa has the best interregional trade track record compared with all other African regions.

\subsection{Trade between Africa and the rest of the world}

From Table 3 it is very clear that the largest component of total trade mainly takes place between the various African regions and the rest of the world. The share of total exports and imports between the various African regions and the rest of the world is between 
Table 3: Regional African trade with the rest of the world

\begin{tabular}{|c|c|c|c|c|c|c|}
\hline \multirow{2}{*}{ Region } & \multicolumn{2}{|c|}{2003} & \multicolumn{2}{|c|}{2007} & \multicolumn{2}{|c|}{2011} \\
\hline & Exports (\%) & Imports (\%) & Exports (\%) & Imports (\%) & Exports (\%) & Imports (\%) \\
\hline South & 88 & 81 & 89 & 84 & 89 & 85 \\
\hline East & 78 & 80 & 75 & 82 & 77 & 82 \\
\hline West & 85 & 84 & 87 & 86 & 87 & 87 \\
\hline Central & 97 & 85 & 97 & 78 & 96 & 84 \\
\hline North & 97 & 95 & 96 & 95 & 92 & 96 \\
\hline
\end{tabular}

Source: www.unctad.org and author's own calculations.

$77 \%$ and $96 \%$. Northern Africa is trading almost exclusively with the rest of the world, with a very small percentage of trade with other African regions.

In Figure 3, trade between Africa and the rest of the world (red) shows the dominance of trade with the rest of the world. It is evident from Figure 3 that, despite the existence of

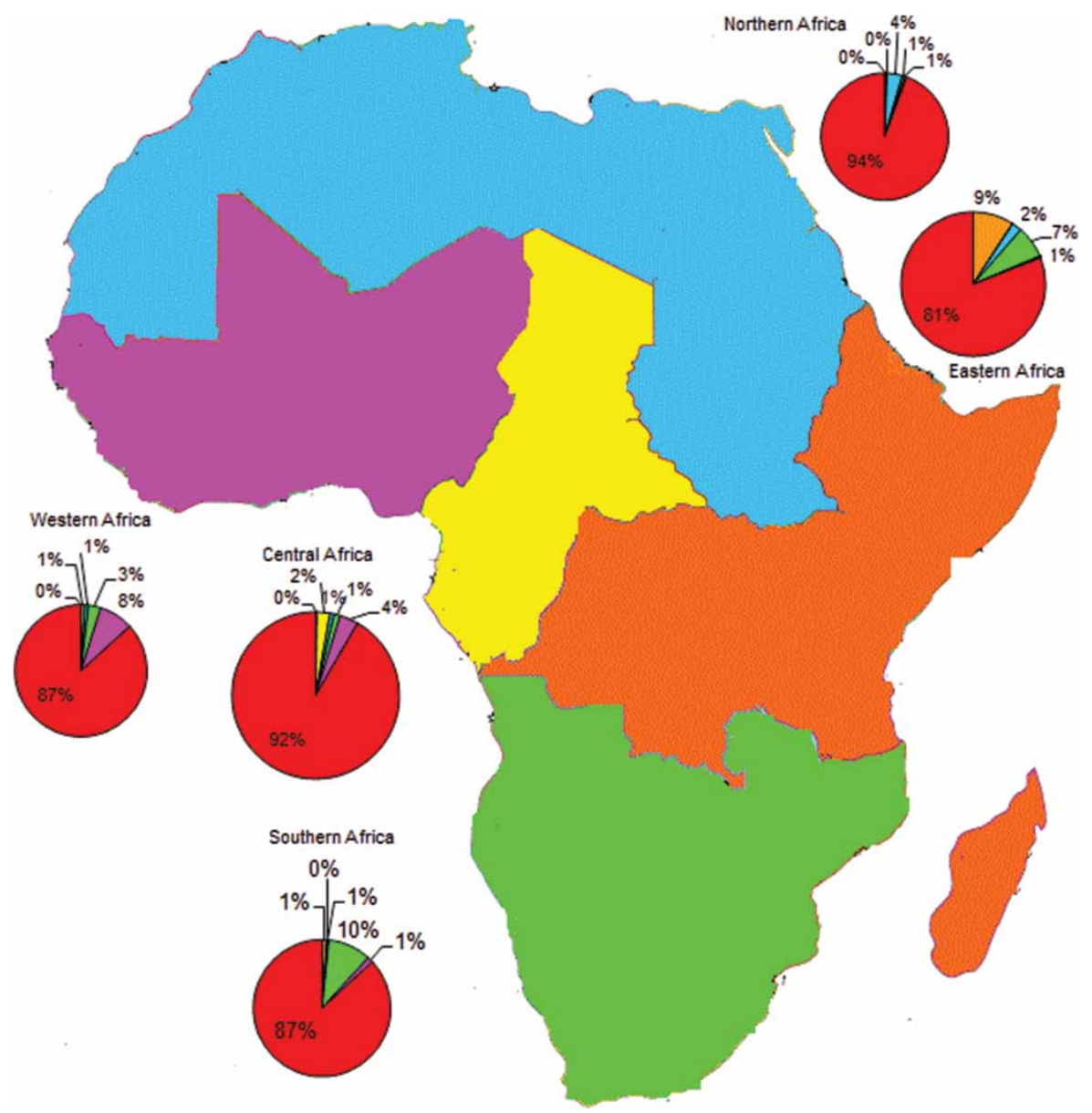

Figure 3: Trade between Africa and the rest of the world (2011)

Source: www.unctag.org 
numerous regional trade arrangements, trade for most African countries is predominantly still linked to trade with the developed nations and former colonial powers.

Given the situation discussed above, one may question whether the existence of numerous trade agreements in Africa actually makes any notable contribution towards higher intra-Africa trade and thus economic growth. It is this situation that spread doubt about the link between the existence of many regional trade communities among African countries and the level of intra-Africa trade. The idea of creating a unified African continent with higher levels of intra-Africa trade, economic growth and improved standards of living is ostensibly still a dream. The process of regional integration on the continent by signing multiple agreements seems to be merely paperwork, without any real economic progress. The perceived theoretical benefits of regional integration has not materialised significantly in anything concrete. Although the continent is a showcase of existing regional agreements, it seems as if it is activity neutral on a practical level because the agreements is not translating into aggressive economic action, expected from such a supposedly integrated environment.

In the absence of an effective regional approach there would be an underinvestment in activities such as cross-border trade facilitation. The creation of regional supply chains should be enhanced. Regional integration and global integration are complements and not substitutes, and by effectively integrating economies on a regional level they should more easily tap into global markets. The key objective of regional integration should be to improve its connectedness with global markets. Focusing only on lowering trade barriers to intra-Africa trade, there is a danger that costs of trade diversion would outweigh the benefits of trade creation.

\section{Conclusion}

Most African countries first have to overcome their demographic and economic limitations before accelerated economic growth can be achieved. The continental and regional economic integration agendas are complex and burdened. The inherent problems of multiple and overlapping memberships are real and the negative impacts are mostly experienced at regional level where it should be tackled. A regional integration strategy that would cause deeper integration is crucial if the continent is to play a rightful role in the global arena. A stand-alone state approach with a firm belief in national sovereignty is too small to be globally competitive. What is needed is a process of deeper regional integration where resources are effectively pooled to form a single competitive market based on the correct comparative advantage and economies of scale to participate in the global market. To strengthen its economic independence and empower the continent globally, it needs uniform economic, fiscal, social and sectoral policies. Effective regional integration has to be complemented by progressively removing artificial barriers to trade. In reality, many African countries are too small, based on economic and demographic size, to influence and direct global trade.

Supplementary to deeper integration, Africa has to address its structural deficiencies and complementary weaknesses by establishing credible and reliant institutions. This includes insufficient production, poor diversification and low levels of competitiveness. In addition, inadequate transportation and communication networks, multiple borderpost controls and delays, and inferior financial markets need to be addressed and improved. A change in trade composition, a policy of industrialisation and improved 
infrastructure should form part of this approach. What is needed is a strong political will, a trained and literate workforce combined with the determination to implement the required economic reforms. It seems that deeper integration on sub-regional levels must be attempted first, then 'growing' towards a closer relationship between the regional groups. Strong integrated markets should first be established as a precondition for signing RTAs. Intra-African trade remains highly concentrated, not only in terms of geography but also with respect to a few strategic commodities.

\section{References}

Aminian, N, Fung, KC \& Francis, N, 2008. Integration of markets vs. integration by agreements. World Bank Policy Research Working Paper No. 4546. The World Bank, Washington, DC.

Coulibaly, S, 2007. Evaluating the trade effect of developing regional trade agreements: A semiparametric approach. World Bank Policy Research Working Paper No. 4220, May, World Bank, Washington, DC.

DFID (Department for International Development), 2011. Regional integration and trade in subSaharan Africa. Trade and Investment Analytical Papers, Topic 7, Department for International Development, London.

Draper, P, Halleson, D \& Alves, P, 2007. SACU, regional integration and the overlap issue in Southern Africa: From spaghetti to cannelloni? Trade Policy Report No. 15. South African Institute of International Affairs, Johannesburg, South Africa.

Ethier, WJ, 1998. The new regionalism. Economic Journal 108(499), 1149-61.

Fiorentino, RV, Verdeja, L \& Toqueboeuf, C, 2007. The Changing Landscape of Regional Trade Agreements: 2006 Update. World Trade Organisation, Geneva.

Foroutan, F \& Pritchett, L, 1993. Intra-sub-Saharan African Trade: is it too little? World Bank Policy Research Working Paper No. 1225. The World Bank, Washington, DC.

Frankel, A \& Rose, A, 2000. An Estimate of the Effects of Currency Unions on Trade and Growth. Kennedy School of Government, Harvard University, Cambridge, MA and Haas School of Business, University of California, Berkley, CA.

Hartzenberg, T, 2011. Regional Integration in Africa. Staff working paper ERSD No. 2011-14.

Hoekman, B, Mattoo, A \& English, P (Eds.), 2002. Development, Trade and the WTO: A Handbook. The World Bank, Washington, DC.

Kalenga, P, 2009. Deepening regional integration in Southern Africa. SADC Secretariat Regional Forum on Enhancing Competitiveness in Southern Africa, 10 February, Balalaika Hotel, Johannesburg, South Africa.

Khandelwal, P, 2004. COMESA and SADC: Prospects and challenges for regional trade integration. IMF Working Paper No. 04/227.

Lewis, JD, 2001. Reform and opportunity: The changing role and patterns of trade in South Africa and SADC. A synthesis of World Bank research. Africa Region Working Paper Series No. 14, World Bank, Washington, DC.

Limao, N \& Venables, AJ, 2001. Infrastructure, geographical disadvantage, transport costs, and trade. World Bank Economic Review 15(3), 451-79.

Longo, R \& Sakkat, K, 2001. Obstacles to expanding intra-African trade. OECD Development Centre Working Paper No. 169, Organisation for Economic Co-operation and Development, Paris.

Mistry, P, 2000. Africa's record of regional co-operation and integration. African Affairs 99, 553-73.

Piazolo, M, 2002. Regional integration in Southern Africa: Motor of economic development? The South African Journal of Economics 70(8), 1198-221.

SADC (Southern African Development Community), 1996. Protocol on Trade. Maseru, August.

Salazar-Xirinachs, JM, 2005. Regional vs. multilateral priorities for developing countries in Latin America and the Caribbean. Paper presented for the International Trade Roundtable on The WTO at 10 Years - The Regional Challenge to Multilateralism, 24 March 1999, Brussels, Belgium. 
Schiff, M \& Winters, LA, 2003. Regional Integration and Development. The World Bank, Washington, DC.

Söderbaum, F, 1996. Handbook of Regional Organisations in Africa. Nordiska Afrikainstitutet, Uppsala.

Soko, M, 2007. The Political Economy of Regional Integration in Southern Africa. Notre-Europe, December, Paris.

Soloaga, I \& Winters, L, 2001. Regionalism in the nineties: What effect on trade? The North American Journal of Economics and Finance 12(1), 1-29.

Te Velde, D, 2008. Regional Integration in African, Caribbean and Pacific countries. A review of the literature. European Commission, DG Development, Brussels, Belgium.

UNCTAD (United Nations Conference on Trade and Development), 2001. E-commerce and Development Report. UNCTAD, Geneva.

UNCTAD (United Nations Conference on Trade and Development), 2009. Economic development in Africa. Strengthening regional economic integration for Africa's development. Report, United Nations Conference on Trade and Development, Geneva.

UNECA (United Nations Economic Commission for Africa), 2010. Assessing Regional Integration in Africa, IV: Enhancing Intra-African Trade. ECA Publications and Conference Management Section (PCMS), Addis Ababa, Ethiopia.

Venables, AJ, 1999. Regional integration: A force for convergence or divergence? World Bank Policy Research Working Paper 2260, December, World Bank, Washington, DC.

Viner, J., 1950. The Customs Union Issue. Oxford University Press, New York.

Winters, LA, 2004. Trade liberalisation and economic performance: An overview. The Economic Journal 114(493), F4-21.

Winters, LA \& Masters, A, 2010. Openness and growth: Still an open question. Address given by Winters to the ESRC Development Economics Annual Conference, January, University of Manchester.

World Bank, 2011. Africa Competitiveness Report. African Development Bank and World Bank, Washington, DC.

\section{Appendix A}

\section{Table A1: UNECA classification of African countries - geographical region}

\section{Region in}

\begin{tabular}{ll} 
Africa & 53 countries included (UNECA classification) \\
\hline South & Angola, Botswana, Lesotho, Malawi, Mauritius, Mozambique, Namibia, South Africa, \\
& Swaziland, Zambia, Zimbabwe (11 countries) \\
East & Burundi, Comoros, Dem Rep of Congo, Djibouti, Ethiopia, Eritrea, Kenya, Madagascar, \\
& Rwanda, Seychelles, Somalia, Tanzania, Uganda (13 countries) \\
West & Benin, Burkina Faso, Cape Verde, Ivory Coast, Gambia, Ghana, Guinea, Guinea-Bissau, \\
& Liberia, Mali, Niger, Nigeria, Senegal, Sierra Leone, Togo (15 countries) \\
Central & Cameroon, Congo, Gabon, Equatorial Guinea, Central African Republic, Sao Tome and \\
& Principe, Chad (7 countries) \\
North & Algeria, Egypt, Libya, Mauritania, Morocco, Sudan, (South Sudan), Tunisia (7 countries)
\end{tabular}




\section{Table A2: Regional economic communities}

\begin{tabular}{|c|c|c|}
\hline Regional economic community & Type & Member countries \\
\hline Arab Maghreb Union (UMA) & Free trade area & Algeria, Libya, Mauritania, Morocco and Tunisia \\
\hline $\begin{array}{l}\text { Common Market for Eastern and } \\
\text { Southern Africa (COMESA) }\end{array}$ & Free trade area & $\begin{array}{l}\text { Burundi, Comoros, Democratic Republic of the } \\
\text { Congo, Djibouti, Egypt, Eritrea, Ethiopia, Kenya, } \\
\text { Libya, Madagascar, Malawi, Mauritius, Rwanda, } \\
\text { Seychelles, Sudan, Swaziland, Uganda, Zambia and } \\
\text { Zimbabwe }\end{array}$ \\
\hline $\begin{array}{l}\text { Community of Sahel-Saharan } \\
\text { States (CEN-SAD) }\end{array}$ & Free trade area & $\begin{array}{l}\text { Benin, Burkina Faso, Central African Republic, Chad, } \\
\text { Ivory Coast, Djibouti, Egypt, Eritrea, Gambia, } \\
\text { Libya, Mali, Morocco, Niger, Nigeria, Senegal, } \\
\text { Somalia, Sudan, Togo, Tunisia, Guinea-Bissau, } \\
\text { Liberia, Ghana, Sierra Leone, Comoros, Guinea, } \\
\text { Kenya, Mauritania, Sao Tome }\end{array}$ \\
\hline $\begin{array}{l}\text { Economic Community of Central } \\
\text { African States (ECCAS) }\end{array}$ & Free trade area & $\begin{array}{l}\text { Angola, Burundi, Cameroon, Central African } \\
\text { Republic, Chad, Congo, Democratic Republic of } \\
\text { the Congo, Equatorial Guinea, Gabon, Sao Tome } \\
\text { and Principe }\end{array}$ \\
\hline $\begin{array}{l}\text { Economic Community of West } \\
\text { African States (ECOWAS) }\end{array}$ & Free trade area & $\begin{array}{l}\text { Benin, Burkina Faso, Cape Verde, Ivory Coast, } \\
\text { Gambia, Ghana, Guinea, Guinea-Bissau, Liberia, } \\
\text { Mali, Niger, Nigeria, Senegal, Sierra Leone and } \\
\text { Togo. }\end{array}$ \\
\hline $\begin{array}{l}\text { Inter-Governmental Authority on } \\
\text { Development (IGAD) }\end{array}$ & Free trade area & $\begin{array}{l}\text { Djibouti, Eritrea, Ethiopia, Kenya, Somalia, Sudan, } \\
\text { Uganda and Tanzania }\end{array}$ \\
\hline $\begin{array}{l}\text { Southern African Development } \\
\text { Community (SADC) }\end{array}$ & Free trade area & $\begin{array}{l}\text { Angola, Botswana, Democratic Republic of the } \\
\text { Congo, Lesotho, Madagascar, Malawi, Mauritius, } \\
\text { Mozambique, Namibia, Seychelles, South Africa, } \\
\text { Swaziland, Tanzania, Zambia, Zimbabwe }\end{array}$ \\
\hline $\begin{array}{l}\text { Economic and Monetary } \\
\text { Community of Central Africa } \\
\text { (CEMAC) }\end{array}$ & Customs union & $\begin{array}{l}\text { Cameroon, Central African Republic, Chad, Congo, } \\
\text { Equatorial Guinea and Gabon }\end{array}$ \\
\hline East African Community (EAC) & Customs union & $\begin{array}{l}\text { Cameroon, Central African Republic, Chad, Congo, } \\
\text { Equatorial Guinea and Gabon }\end{array}$ \\
\hline $\begin{array}{l}\text { Southern African Customs Union } \\
\text { (SACU) }\end{array}$ & Customs union & Botswana, Lesotho, Namibia, South Africa, Swaziland \\
\hline $\begin{array}{l}\text { West African Economic and } \\
\text { Monetary Union (UEMOA) }\end{array}$ & Customs union & $\begin{array}{l}\text { Benin, Burkina Faso, Ivory Coast, Guinea-Bissau, } \\
\text { Mali, Niger, Senegal, Togo }\end{array}$ \\
\hline
\end{tabular}

Source: Various REC websites. 
Table A3: Main export products (2011)

\begin{tabular}{|c|c|c|c|}
\hline Region & Exports to & Type of products (\% of exports) & \\
\hline \multirow[t]{5}{*}{ South } & south & Petroleum, oils or bituminous ( $16 \%)$ & Other $(80 \%)$ \\
\hline & east & Flat rolled products, iron, non-alloy steel $(10 \%)$ & Other $(77 \%)$ \\
\hline & west & Motor vehicles $(16 \%)$ & Other $(77 \%)$ \\
\hline & central & Ships boats and floating structures $(11 \%)$ & Other $(70 \%)$ \\
\hline & north & Copper (34\%), Motor vehicles (31\%) & Other $(25 \%)$ \\
\hline \multirow[t]{5}{*}{ East } & east & Vegetables $(8 \%)$ & Other $(81 \%)$ \\
\hline & south & Gold, non-monetary $(12 \%)$ & Other $(73 \%)$ \\
\hline & west & Liquefied propane \& butane $(12 \%)$ & Other $(71 \%)$ \\
\hline & central & Fixed vegetable fat $\&$ oils (19\%) & Other $(61 \%)$ \\
\hline & north & Tea $(33 \%)$ & Other $(43 \%)$ \\
\hline \multirow[t]{5}{*}{ West } & west & Petroleum, oils or bituminous (53\%) & Other $(42 \%)$ \\
\hline & south & Petroleum, oils or bituminous (56\%) & Other $(8 \%)$ \\
\hline & east & Petroleum, oils or bituminous (43\%) & Other $(48 \%)$ \\
\hline & central & Petroleum, oils or bituminous (79\%) & Other $(18 \%)$ \\
\hline & north & Liquefied propane \& butane $(21 \%)$ & Other $(54 \%)$ \\
\hline \multirow[t]{5}{*}{ Central } & central & Ships, boats and floating structures (34\%) & Other $(39 \%)$ \\
\hline & south & Ships, boats and floating structures $(45 \%)$ & Other $(22 \%)$ \\
\hline & east & Petroleum, oils or bituminous (64\%) & Other $(24 \%)$ \\
\hline & west & Petroleum, oils or bituminous ( $29 \%)$ & Other $(53 \%)$ \\
\hline & north & Wood $(32 \%)$ & Other $(37 \%)$ \\
\hline \multirow[t]{5}{*}{ North } & north & Liquefied propane \& butane $(20 \%)$ & Other $(67 \%)$ \\
\hline & south & Gold, non-monetary $(75 \%)$ & Other $(21 \%)$ \\
\hline & east & Petroleum, oils or bituminous (11\%) & Other $(75 \%)$ \\
\hline & west & Fish $(19 \%)$ & Other $(66 \%)$ \\
\hline & central & Fish $(17 \%)$ & Other $(68 \%)$ \\
\hline
\end{tabular}

Source: www.unctad.org 
Table A4: Main import products (2011)

\begin{tabular}{|c|c|c|c|}
\hline Region & Imports from & Type of products (\% of imports) & \\
\hline \multirow[t]{5}{*}{ South } & south & Petroleum, oils or bituminous (11\%) & Other $(79 \%)$ \\
\hline & east & Copper ores \& concentrates $(38 \%)$ & Other $(42 \%)$ \\
\hline & west & Petroleum, oils or bituminous (92\%) & Other $(6 \%)$ \\
\hline & central & Electric current $(17 \%)$ & Other $(51 \%)$ \\
\hline & north & Petroleum, oils or bituminous $(16 \%)$ & Other $(72 \%)$ \\
\hline \multirow[t]{5}{*}{ East } & east & Vegetables $(20 \%)$ & Other $(79 \%)$ \\
\hline & south & Petroleum, oils or bituminous $(7 \%)$ & Other $(81 \%)$ \\
\hline & west & Petroleum, oils or bituminous ( $47 \%)$ & Other $(43 \%)$ \\
\hline & central & Civil engineering \& contractors' equipment (40\%) & Other $(45 \%)$ \\
\hline & north & Petroleum, oils or bituminous (14\%) & Other $(68 \%)$ \\
\hline \multirow[t]{5}{*}{ West } & west & Petroleum, oils or bituminous ( $25 \%)$ & Other $(50 \%)$ \\
\hline & south & Motor vehicles (12\%) & Other $(83 \%)$ \\
\hline & east & Liquefied propane \& butane (13\%) & Other $(70 \%)$ \\
\hline & central & Petroleum, oils or bituminous $(20 \%)$ & Other $(58 \%)$ \\
\hline & north & Fish $(20 \%)$ & Other $(63 \%)$ \\
\hline \multirow[t]{6}{*}{ Central } & central & Petroleum, oils or bituminous ( $36 \%)$ & Other $(36 \%)$ \\
\hline & & Ships, boats \& floating structures ( $28 \%)$ & \\
\hline & south & Ships, boats \& floating structures (38\%) & Other $(51 \%)$ \\
\hline & east & Liquefied propane \& butane $(23 \%)$ & Other $(58 \%)$ \\
\hline & west & Petroleum, oils or bituminous $(80 \%)$ & Other $(18 \%)$ \\
\hline & north & Fish $(30 \%)$ & Other $(60 \%)$ \\
\hline \multirow[t]{5}{*}{ North } & north & Liquefied propane \& butane (19\%) & Other $(64 \%)$ \\
\hline & south & Copper $(32 \%) \&$ Motor vehicles $(31 \%)$ & Other $(30 \%)$ \\
\hline & east & Tea $(46 \%)$ & Other $(37 \%)$ \\
\hline & west & Coffee $(25 \%) \&$ Liquefied propane \& butane $(21 \%)$ & Other $(40 \%)$ \\
\hline & central & Wood $(43 \%) \&$ Coffee $(27 \%)$ & Other $(30 \%)$ \\
\hline
\end{tabular}

Source: www.unctad.org 